\title{
Individual Parental Leave for Fathers: Promoting Gender Equality in Norway
}

\author{
Elin Kvande
}

\section{Introduction}

How to increase fathers' use of parental leave is a relevant question for countries that want to promote men's involvement in childrearing and gender equality more broadly. As countries are searching for instruments that can effectively promote a greater involvement of fathers in care work, the Nordic parental leave experiences may be useful. The Nordic countries, Denmark, Finland, Iceland, Norway and Sweden, have followed similar trajectories of development, not exactly following the same timeline, but clearly inspired by each other. All of them have introduced special incentives for fathers to use leave after having experienced that simply offering shared parental leave was not enough to get fathers to use it. Norway was the first country to introduce a fathers' quota in 1993, followed by Sweden 2 years later, Denmark in 1998 (until 2002 when it was discontinued) and Iceland in 2000. Finland had a bonus system providing fathers with 12 extra days if they used 12 days of the shared parental leave. This was changed to an individual, non-transferable right, a father's quota in 2013.

In comparative research on gender equality, the Nordic welfare states are analysed as including regulations that support both working mothers and fathers (Pascall 2012). Equality between men and women is encouraged through an individual earner-carer regime (Sainsbury 1999). Important policy measures in this regime include publicly funded parental leave schemes, universal, high quality daycare, and access to reduced work hours. These are the same social arrangements

\footnotetext{
E. Kvande $(\bowtie)$

Department of Sociology and Political Science, Norwegian University of Science and Technology, Trondheim, Norway

e-mail: elin.kvande@ntnu.no

(C) The Author(s) 2022

M. Grau Grau et al. (eds.), Engaged Fatherhood for Men, Families and Gender

Equality, Contributions to Management Science,

https://doi.org/10.1007/978-3-030-75645-1_8
} 
as Gornick and Meyers (2009) pinpoint as important in order to create a dual-earner/ dual-caregiver society.

A comprehensive research literature on parental leave has evolved during the last 20 years. In fact, the study of parental leave is in the forefront of comparative social policy research focusing on gender equality (Ray et al. 2010). This strong interest in parental leave policies must be understood on the basis of these policies having the potential to change women's position in employment and engaging men in caregiving. Parental leave policy rights and designs vary substantially across countries (Blum et al. 2018) and the effect of the different leave systems on gender equality is also debated (Morgan 2008; Moss and Deven 1999; Moss et al. 2019).

In their analysis of what is needed to achieve "strong gender equality" in family and working life, Brighouse and Wright (2008) distinguish between three types of policies: (1) equality-impeding policies (e.g., unpaid caregiving leaves), (2) equalityenabling policies (e.g., paid caregiving leaves given to families), and (3) equalitypromoting policies (e.g., paid caregiving leaves given to individuals rather than families). According to them, shared parental leave granted to the family enables parents to adopt egalitarian strategies, but do not represent strong incentives for fathers to use the leave rights. Leave policies that promote equality are exemplified by paid leave granted to individual parents, which lapses if it is not used. Brighouse and Wright find that this type of leave is necessary for breaking down the cultural barriers to gender equality in family and working life.

Using this as a point of departure, this paper will describe the design elements of the Norwegian parental leave system for fathers and examine how it works as a regulatory measure to promote equality in care work. The paper will thus address the request put forward by Ray et al. (2010), in which they point out that surprisingly little research has been carried out that links the design of leave policies to their outcomes. There are especially few empirical studies assessing which parental leave schemes are gender egalitarian by design (Bartel et al. 2018; Dearing 2016), and this has left a gap in cross-national literature on leave policies.

\section{Designing Individualized Parental Leave for Fathers}

Research on social policy in European welfare states has increasingly focused on the norm of individualization, thus indicating a social policy that treats women and men as individual workers (Lewis 2015). Similarly Daly (2011) suggests applying the concept of "individualization processes" in order to capture change in family policies which implies a shift away from policy assumptions based on the male breadwinner/female carer model and, instead, expecting all adults to be both breadwinners and carers. Individualistic policy designs, however, do not necessarily include gender equality (Ray et al. 2010). Therefore, how social policies relate to this parameter dictates whether they are classified as supporting an individualistic or familistic model according to Daly (2011). 
Research has documented that to give parental leave rights to individuals, rather than to families, is more effective when it comes to getting fathers to take leave (Duvander and Lammi-Taskula 2012; Haas and Rostgaard 2011; Eydal and Gíslason 2013). In their analyses of institutions that support gender equality in parenthood and employment, Gornick and Meyers (2009) point to the importance of individualized parental leave, as well as the principle of non-transferability, as in the fathers' quota. They suggest a period of 6 months leave to each parent, which cannot be transferred to the other parent. This is also what was suggested in a white paper produced by an expert committee for the Norwegian government in 2017 (NOU 2017).

The international literature on specific policy provisions for parental leave is expanding (McKay and Doucet 2010), particularly concerning fathers. Within research based on Nordic experiences, there is a consensus that parental leave rights given to individuals, rather than to families, are most likely to get fathers to take leave (Rostgaard 2002; Duvander and Lammi-Taskula 2012; Haas and Rostgaard 2011; Eydal et al. 2015). The father's quota in Nordic countries has been successful in involving fathers in taking care of their young babies (Haas and Rostgaard 2011; Brandth and Kvande 1998, 2018). These results are also found internationally (Moss and Kamerman 2009; Gornick and Meyers 2009; Miller 2013; Harvey and Tremblay 2019). Documented findings from a number of countries have shown that the shared parental leave (and thus optional for fathers) is mostly used by mothers (O'Brien and Wall 2017; Ray et al. 2010; Fougner 2012; Gíslason and Eydal 2013). Fathers taking leave challenge the traditional gender norm that mothers are the primary caregivers of small children.

This chapter explores fathers' understandings and experiences with the father's quota (i.e., the leave programs), which, according to Brighouse and Wright (2008), may promote equality. Studies of the Norwegian leave programme comparing the father's quota to the more optional schemes of shared parental leave and cash allowances were conducted some years after the introduction of the father's quota (Brandth and Kvande 2009) This research documented that mandatory leave for fathers made it easier for them to use the father's quota to set boundaries against the demands of work, thus reserving uninterrupted father-child time. It was also pointed out that a statutory earmarking of the father's quota lifts the decision of who should take leave from the family up to the institutional level, where it would apply to "all" fathers. The father's quota became a pre-negotiated right for men also in terms of the workplace, and it was supposed to eliminate the need to negotiate individually with the employer over the use of the father's quota.

This chapter examines the impact of the expansion and maturation of the father's quota. Using Brighouse and Wright's conceptual framework the chapter explores how the Norwegian leave policies which are an individual right are experienced by the fathers in our latest study. 


\section{The Norwegian Parental Leave System for Fathers}

In 1978 the leave rights in Norway were changed so that most of the leave could be shared between the parents, moving away from the idea of maternity leave as a special right only for women. By granting fathers the right to shared leave, legislation signaled a new view of men's responsibilities and participation in caregiving. In the years to come, fathers, however, rarely used shared parental leave so the policy did not promote more equal parenting. To advance that goal, an earmarked, non-transferable leave of 4 weeks for fathers was introduced in 1993. At the same time the total leave period was extended from 35 to 42 weeks with $100 \%$ wage compensation. Proponents argued that a quota would give a strong signal to parents as well as to employers that men as well as women are parents with obligations and rights as caregivers. Children's need for their fathers was also emphasized in the debate. Since then the father's quota has developed gradually, extended to 14 weeks and then reduced to 10 weeks in 2014 following the politics of the parties in power.

Both mothers and fathers have individual, non-transferable leave rights in addition to shared leave rights. Currently, mothers have an earmarked period of 13 weeks, of which 3 must be taken before the child's birth. Beginning in 2014, 26 weeks are sharable between mothers and fathers. If the parents choose lower pay ( $80 \%$ of wages), the leave is extended by 10 weeks. The fathers' quota is now 10 weeks. In addition to parental leave, fathers have 2 weeks of paternity leave to be taken after the birth of the child to assist the mother. There are no public records of the usage of paternity leave, as wage compensation is based on collective agreements and paid by employers.

The fathers' quota gives male employees the right and obligation to provide care during the child's early years of life. The principal aim of this leave is to break away from the norm that men serve as breadwinners and women as caregivers even if they, too, are employed outside the home. The system is based on the principle that parents "earn" the right through participation in working life. To qualify for parental leave, both mothers and fathers have to be in the workforce for 6 of the last 10 months prior to the birth. If the mother is not eligible, the father loses his right to the fathers' quota but not to the shared leave if the mother returns to studies or takes on employment. This type of eligibility encourages both parents to combine work and family obligations as it is built on a model in which both mothers and fathers are employed. Since its introduction, the fathers' quota has been widely used, and more than $90 \%$ of eligible fathers use all or part of this leave (Kitterød et al. 2017). Mothers take most of the shared leave days, and, for most couples, mothers' leave is considerably longer than fathers'. 


\section{Data and Method}

The analysis is based on a qualitative study in which 22 fathers who had taken parental leave were interviewed in 2012 and 2013. The interviews were carried out during the second year after the child's birth. Thus, the fathers in the sample had rights to 10 or 12 weeks of individual leave and 27 or 26 weeks of shared leave if they chose $100 \%$ compensation. If they chose the $80 \%$ compensation option, the leave would have been prolonged accordingly. The fathers were recruited by contact with various workplaces and then snowballing. The interviewees had to have become fathers after the fathers' quota was expanded to 10 weeks in 2009 , as we were interested in their experiences of relatively long leaves. The length of the leave taken by the sample varied; most fathers had taken the father's quota of 10 or 12 weeks, but 8 had also taken all or part of the shared parental leave.

The research team endeavoured to find interviewees with varied social backgrounds. Half had higher education (masters level), while the other half either had a medium level education at the bachelor level (6) or no education beyond high school (5). The fathers had a wide range of occupations, including engineers, artisans, teachers, office workers, consultants, and administrative, healthcare, and technical staff. They worked in organizations of various sizes and composition.

As Norwegian leave rights are employment based (i.e., accrued by the participation of both parents in working life), all the fathers and most of their children's mothers (except for three) were in paid employment prior to the birth of their child and had a right to parental leave. Half of the fathers were employed by private companies, but only one was self-employed, and one, a student, was temporarily employed. Except for this father, all worked full time. All the fathers lived together with the mother and their child, and the child who triggered the interview could be the father's first, second, or third child. Most fathers were in their 30s, though they ranged between 27 and 43. Eight of the fathers (36\%) had taken shared parental leave. Two of them had taken all the shared parental leave available, as the mothers were not eligible due either to having returned to work or school.

The interviews were semi-structured and lasted between 1 and $2 \mathrm{~h}$. The data was collected by a research team, in which the author participated. To preserve anonymity, the full name and contact details of the interviewees were not recorded, and fictitious names have been used. The fathers were mostly interviewed in their homes. The fathers' understandings were based on their own experiences and what they observed with colleagues and friends. The recorded transcripts were examined to identify each father's stories about their experiences at their respective workplaces. We also asked hypothetical questions about what would have happened if there were no father's quota. The next stage was interpreting these themes in a dialogue with the literature. The findings are illustrated by quotations. 


\section{Experiencing the Fathers' Quota Design}

\subsection{The Fathers' Quota as a Norm}

The fathers' quota enjoys a high degree of support among fathers in Norway (Hamre 2017), and studies on fathers' quota usage have pointed out that it has become a norm among men in Norway to take leave when they have become fathers (Halrynjo and Kitterød 2016; Naz 2010). Our findings also support this claim.

"There was no doubt that I should take the fathers' quota," said Steinar, an engineer with two daughters. According to Ivar, "For fathers to have 12 weeks is quite natural in a way... . It has become incorporated." Their viewpoints illustrate that the fathers' quota is a matter of fact. Twenty-five years after it was introduced, taking leave seems to be taken for granted among fathers in Norway. That it is based in law, earmarked, and non-transferable identifies this leave with fathers and defines it as their right and 'property.'

It is also interpreted as an obligation and seen as a signal from the welfare state that fathers are expected to engage in taking care of small children. "Society reacts if you don't take it, right," Harold said. Lars, an engineer, claimed that the quota "feels like something you ought to ... that it's something you should take, really... . It feels like there's pressure on you to take it. That ... if you want to be a good parent, or a good father, then you have to take the daddy leave." Several fathers indicated that if they had not taken the fathers' quota, they would have to explain themselves to others.

Fathers' leave-taking is supported by social norms of good fatherhood that these fathers seem to have incorporated into their identities. As the next section shows, fatherhood has also been incorporated into their practices as employees.

\subsection{Employers' Support of Fathers' Caregiving Responsibilities}

Many of the fathers in the sample strongly felt that having a quota given to them as employees was an unconditional strength in relation to work, and that it would have been much more difficult to gain support from employers if it were not for their legal right to the fathers' leave. "It makes your position stronger when the quota is based in law," said Geir. Kristoffer and many others believed that if the father's quota was not retained as a father-specific right, they would fail in their negotiations over leave with their employer. Since the fathers' quota is statutory, employers have little leeway to adopt discriminatory practices.

The fathers' sense of entitlement becomes explicit when Steinar reflects on how he would have had to argue in his previous job as a consulting engineer with a small company. "It was very intense with a call on us to work $80 \mathrm{~h}$ a week and perform all we could with lots of pressure and bonuses. In this place, taking leave would have 
been frowned upon. But still, should you have to fight for your rights?" Moreover, the fathers' leave is paid by the state rather than the employer. Comparing his right to the fathers' quota with his right to paid holidays, Steiner said that if he did not take his "3 months 'holiday' with pay," he would lose it. Entitlements to paid time off are acceptable in working life. To have to argue with his employer about his childcare responsibilities would not work as well, Steinar claimed.

None of the fathers in the study reported that they had experienced any serious problems with their current employers when planning to use their entitlement (Brandth and Kvande 2019a, b). Indeed, men seem to be expected to take the fathers' leave by their employers and colleagues. Harold, a schoolteacher, said: "It was all right, and it was expected! It would have been more of an issue if I hadn't taken it. Public workplaces have to play by the rules." For fathers, it seems inevitable that working life must adapt to the regulations of the welfare state. Christian, a senior advisor in the municipal administration, pointed out that even though the fathers' quota might sometimes represent challenges for workplaces, organizations do adapt to this legislation.

The fathers' quota has existed for a quarter century, which means that men who have advanced to management positions in some organizations have taken fathers' leave themselves. That experience influences what is considered fair and feasible. Tore, a doctor in a large hospital, described how his leave-taking was received by his director, a 60-year-old chief physician: "He is up to date on the father's quota... . He has had young children himself.... And I am not the first father to be in this situation." Steinar, too, explained that his bosses are fathers: "They are 54 and 62 , and both were home with their children at a time when it was much less common than now. So, they pushed me, saying 'Steinar, it is clear that you must stay home,' and 'Are you sure you won't take a bit longer leave?' They said so even if it was bad for the job." Likewise, Sivert described his boss as very positive: "He understood me very well. I suppose he is 50 years, so he is very up to date." His boss was eager to help him find out about the regulations concerning the father's quota and the rest of the parental leave system. Sivert considered him a "modern" man who regarded fathers' involvement with children as important. Another father interviewed, Hans, said:

I think most employers today live in the modern world and understand that they must live up to that. This is how it is. They need employees who are happy with their job and have a good family life. Now, we see that both managers and middle managers in companies, 35 to 40 years old, experience the same tensions concerning career, childcare, parental leaves and work hours. I have a mate who is manager of marketing, only a few years older than me in a top job; he had four months daddy leave, so that says a lot.

Fathers are more likely to take up family friendly working practices if they can "compare themselves with other fathers and realize that it is feasible to do so" (Lewis and Stumbitz 2017: 230). The fathers we interviewed reported that as leave takers they did not stand out in any way. Hans, a communications advisor in a transport company, told us that at his workplace "many of my male colleagues had a child at about the same time as me, which was great! We were about three or four who had kids within a 2- or 3-month span. In addition, many employees here have small 
children." The norms that are produced by these practices make it easy for fathers to take leave and for organizations to plan for it. Dahl et al. (2014), who studied the peer effect of father quota usage, found that fathers are even more likely to take the quota if their colleagues did. The effect was greatest if a manager at a higher level in the organization had taken the fathers' leave.

Many of the fathers confidently portrayed the quota as their leave. In so doing, they conveyed a sense of entitlement and beliefs about what is right and fair. Hobson and Morgan (2002: 14) hold that family friendly policies provide men with discursive resources with which they can make claims upon their employers. For instance, Ivar communicated that it was he who controlled how much and when he would work, and he was not afraid to insist on his priorities.

\subsection{Empowered as Caregivers}

The fathers communicated an identity as competent caregivers and attributed this to their time on leave when they had gotten to know the child well. They thought that children benefit from close contact with fathers, and that fathers are significant caregivers for children. Erlend said:

\footnotetext{
"It is quite unfair that only mothers are regarded as important for the children. Speaking as a man I think this is a new situation for gender equality... . I have been able to prove that I can be just as good a carer as the mother. I think it is super important! It increases men's selfconfidence and society's confidence in men as caregivers."
}

Regarding it as unfair that only mothers are given support as caregivers, these men see the fathers' quota as remedying this injustice. They justify their entitlement to leave as based on their ability to care for their small children and think the fathers' quota contributes to their being seen as needed and important caregiving parents. They feel entitled to both the joys and burdens of childcare, and they stress that the fathers' quota represents an opportunity to develop an autonomous relationship with their children. "Being home on leave has in a way laid the foundation for the contact we [father and child] have today. A lot will happen later in life, but this is the basis," Didrik said.

The quota as a father-specific right simplifies negotiations with the mother. Sivert realized that this was the point of earmarking it: "This is why they designed it like that. If not, nothing would have come of it. Then the mother would have taken the whole leave." He thought that to many people it is still not obvious that the father will choose to stay home with the child. To avoid making parental leave only mothers' leave, he said, it was important that things were not "made completely flexible."

Employed fathers view the fathers' quota as an entitlement, a support from the welfare state for them to be active caregivers. There are strong moral obligations for fathers to take the father's quota and for employers to accept it. This finding seems important in understanding the high use of the quota among fathers in Norway. 


\section{Practical Recommendations}

These findings illustrate that the design of the father's quota as a statutory, earmarked, and non-transferrable right for fathers promotes the fathers' use of leave and hence equality. The earmarking, and the fact that it cannot be transferred to the mother, renders it unnecessary for fathers to negotiate with the mother about this leave. The father's quota is also an important bargaining chip in relation to the job. Even if fathers have stories about situations where the employers do not want the father to take leave, employers are most often described as positive towards the father's leave, and the interviews include few personally experienced stories about employers impeding the fathers from taking leave. We interpret this as a sign that the father's quota as a legal earmarked right may have contributed to making visible and promoting the fact that employed men are also fathers and "encumbered" with caregiving responsibilities as much as employed mothers. Thus, in order to promote gender equality, policy makers should choose paid parental leave given to individuals rather than to families. These policies help the equality processes in work organizations through normalizing that both female and male employees are parents.

Much of the evidence indicates that if there were no earmarked and non-transferrable leave for the father that was based in law, reluctant fathers would not have taken any leave and mothers may have been unwilling to give up leave to share with them. There are ambivalent and hesitant fathers who would then choose differently. This also shows that leave for many fathers is not something that is fully in place as an accepted and taken-for-granted practice. These findings thus support other research on fathers' use of leave which have shown that the design characteristics of father's quota represents a strong incentive for greater involvement on the part of fathers.

Considering these findings, it is interesting that the EU Commission in 2019 introduced a new package on work-life balance to ensure better leave provisions and care facilities for working parents in all EU member states. The existing EU Directives on maternity and parental leave are regarded as outdated as they have largely failed to improve gender equality, neither expanding women's participation in the labour market, nor encouraging men to use leave provisions and take a greater share of caring responsibilities.

\section{References}

Bartel AP, Rossin-Slater M, Ruhm CJ, Stearns J, Waldfogel J (2018) Paid family leave, fathers' leave-taking, and leave-sharing in dual-earner households. J Policy Anal Manage 37(1):10-37

Blum S, Koslowski A, Macht A, Moss P (2018) 14th annual international review of leave policies and research 2018. International network on leave policies \& research. https://www. leavenetwork.org/annual-review-reports/archive-reviews/

Brandth B, Kvande E (1998) Masculinity and child care: the reconstruction of fathering. Sociol Rev 46(2):293-313 
Brandth B, Kvande E (2009) Gendered or gender neutral care policies for fathers? Ann Am Acad Polit Social Sci 624(1):177-189

Brandth B, Kvande E (2018) Masculinity and fathering alone. Men Masculinities 21(1):72-90

Brandth B, Kvande E (2019a) Fathers' sense of entitlement to ear-marked and shared parental leave. Sociol Rev 67(5):1154-1169

Brandth B, Kvande E (2019b) Workplace support of fathers' parental leave use in Norway. Community Work Fam 22:43-57

Brighouse H, Wright EO (2008) Strong gender egalitarianism. Polit Soc 36(3):360-372

Dahl GB, Løken KV, Mogstad M (2014) Peer effects in program participation. Am Econ Rev 104 (7):2049-2074

Daly M (2011) What adult worker model? A critical look at recent social policy reform in Europe from a gender and family perspective. Soc Polit 18(19):1-24

Dearing H (2016) Gender equality in the division of work: how to assess European leave policies regarding their compliance with an ideal leave model. J Eur Soc Policy 26(3):234-247

Duvander A-Z, Lammi-Taskula J (2012) Parental leave. In: Gíslason IV, Eydal GB (eds) Parental leave, childcare and gender equality in the Nordic countries. Nordic Council of Ministers, Copenhagen, pp 31-64

Eydal GB, Gíslason IV (2013) Tredelt permisjon og lang fedrekvote: Erfaringer fra Island. In: Brandth B, Kvande E (eds) Fedrekvoten og den farsvennlige velferdsstaten. Universitetsforlaget, Oslo, pp 222-237

Eydal GB, Gíslason IV, Rostgaard T, Brandth B, Duvander A-Z, Lammi-Taskula J (2015) Trends in parental leave: has the forward march of gender equality halted? Community Work Fam 18 (2):161-181

Fougner E (2012) Fedre tar ut hele fedrekvoten - også etter at den ble utvidet til ti uker. [Fathers use the whole father's quota - also after extension]. Arbeid og velferd 2:71-77

Gíslason IV, Eydal GB (2013) Parental leave, childcare and gender equality in the Nordic countries. Nordic Council of Ministers, Copenhagen

Gornick JC, Meyers MK (eds) (2009) Gender equality. Transforming family divisions of labor. Verso, London

Haas L, Rostgaard T (2011) Fathers' right to paid parental leave in the Nordic countries: consequences for the gendered division of care. Community Work Fam 14(2):177-195

Halrynjo S, Kitterød RH (2016) Fedrekvoten - norm for fedres permisjonsbruk i Norge og Norden: En litteraturstudie. Report 2016:06. ISF, Oslo. https://samfunnsforskning.brage.unit.no/ samfunnsforskning-xmlui/handle/11250/2442339

Hamre K (2017) Fedrekvoten - mer populær enn noen gang. Samfunnsspeilet, 1. Statistics Norway. https://www.ssb.no/befolkning/artikler-og-publikasjoner/fedrekvoten-mer-populaer-enn-noengang

Harvey V, Tremblay D-G (2019) The workplace: challenges for fathers and their use of leave. In: Moss P, Duvander A-Z, Koslowski A (eds) Parental leave and beyond. Recent international developments, current issues, future directions. Policy Press, Bristol, pp 223-240

Hobson B, Morgan DHJ (2002) Introduction. In: Hobson B (ed) Making men into fathers. Cambridge University Press, Cambridge, pp 1-23

Kitterød RH, Halrynjo S, Østbakken KM (2017) Pappaperm? Fedre som ikke tar fedrekvote - hvor mange, hvem og hvorfor? Report 2017: 2. ISF, Oslo

Lewis J (2015) The decline of the male breadwinner model. Soc Polit 8(2):152-169

Lewis S, Stumbitz B (2017) Research on work and family: some issues and challenges. In: Liebig B, Oechsle M (eds) Fathers in work organizations. Barbara Budrich, Berlin, pp 227-244

McKay L, Doucet A (2010) "Without taking her leave": a Canadian case study of couples' decisions on fathers' use of paid parental leave. Fathering 8(3):300-320

Miller T (2013) Shifting out of neutral on parental leave. Making fathers' involvement explicit. Public Policy Res 19(4):258-262

Morgan KJ (2008) The political path to a dual earner/dual carer society: pitfalls and possibilities. Polit Soc 36(3):403-420 
Moss P, Deven F (1999) Parental leave: progress or pitfall? Research and policy issues in Europe. Vlaamse Gemeenschap, Brussels

Moss P, Kamerman SB (2009) Introduction. In: Kamerman S, Moss P (eds) The politics of parental leave policies. Policy Press, Bristol, pp 1-13

Moss P, Duvander A-Z, Koslowski A (eds) (2019) Parental leave and beyond: recent developments, current issues, future directions. Policy Press, Bristol

Naz G (2010) Usage of parental leave by fathers in Norway. Int J Sociol Soc Policy 30 $(5 / 6): 313-325$

NOU (2017) NOU 2017:6 Offentlig støtte til barnefamiliene [Public support for families with children]. Government of Norway. Ministry of Children and Equality, Oslo. https://www. regjeringen.no/no/dokumenter/nou-2017-6/id2540981/

O’Brien M, Wall K (eds) (2017) Comparative perspectives on work-life balance and gender equality: fathers on leave alone. Springer, London

Pascall G (2012) Gender equality in the welfare state? The Policy Press, Bristol

Ray R, Gornick JC, Schmitt J (2010) Who cares? Assessing generosity and gender equality in parental leave policy designs in 21 countries. J Eur Soc Policy 20(3):196-216

Rostgaard T (2002) Setting time aside for the father: father's leave in Scandinavia. Community Work Fam 5(3):343-370

Sainsbury D (1999) Gender, policy regimes and politics. Chapter 8. In: Sainsbury D (ed) Gender and welfare state regimes. Oxford University Press, New York

Open Access This chapter is licensed under the terms of the Creative Commons Attribution 4.0 International License (http://creativecommons.org/licenses/by/4.0/), which permits use, sharing, adaptation, distribution and reproduction in any medium or format, as long as you give appropriate credit to the original author(s) and the source, provide a link to the Creative Commons license and indicate if changes were made.

The images or other third party material in this chapter are included in the chapter's Creative Commons license, unless indicated otherwise in a credit line to the material. If material is not included in the chapter's Creative Commons license and your intended use is not permitted by statutory regulation or exceeds the permitted use, you will need to obtain permission directly from the copyright holder.

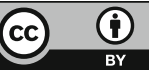

